This is a personal author version of the article published by Elsevier Ltd. in its journal Bioresource Technology. This version is made available by the authors as voluntary posting on open web sites operated by author or author's institution for scholarly purposes only, in accordance with the journal's author permission rights.

This version and the published journal version are identical in content, but contain modifications in formatting or editing. The full citation of the published journal article is as follows:

Kusch, Sigrid; Oechsner, Hans; Jungbluth, Thomas: Biogas production with horse dung in solidphase digestion systems. Bioresource Technology 99, 2008, 1280-1292

doi:10.1016/j.biortech.2007.02.008

http://www.sciencedirect.com/science/article/pii/S0960852407001484

http://www.sciencedirect.com/science/journal/09608524/99/5

http://www.journals.elsevier.com/bioresource-technology/

\title{
Biogas production with horse dung in solid-phase digestion systems
}

Sigrid Kusch*, Hans Oechsner, Thomas Jungbluth

University of Hohenheim, Institute for Agricultural Engineering, State Institute for Machinery and

Construction in Agriculture, Garbenstraße 9, D-70599 Stuttgart, Germany

\begin{abstract}
Experiments on methanogenesis from horse dung were conducted in laboratory-scale batch reactors in order to determine the substrate performance in a solid-phase digestion process, more specifically in terms of potential energy recovery and suitable process technology. Dung from a horse stable with straw bedding was used. The temperature was kept in the mesophilic range. In the percolation process (with process water sprinkled over the stacked biomass) a proportion of $10-20 \%$ of solid inoculum (pre-digested horse dung) was found to be suitable. Comparative experiments with both percolation and flooding revealed a higher biogas production per volume for the flooded process, as no addition of solid inoculum was necessary. Methane yield from fresh material was similar in both processes: around $170 \mathrm{~L}_{\mathrm{N}} \mathrm{CH}_{4}$ per $\mathrm{kg}$ VS added was obtained in six-week cycles with untreated material under optimized conditions. Methane production was increased after chopping the substrate. Pre-aeration resulted in decreased methane production.
\end{abstract}

\footnotetext{
* Corresponding author. Fax: +49 711 45922519. Tel: +49 71145923514

E-mail address: kuschsig@uni-hohenheim.de
} 
Keywords: anaerobic digestion, dry digestion, high-solids digestion, percolation, flooding

\section{Introduction}

Digestion with an elevated content of total solids (TS) is widely used for municipal solid waste (MSW). Since 1993, what are called dry digestion plants (>20\% TS in the feed) have been constructed more often than wet digestion plants ( $<10 \%$ TS in the feed) (Bolzonella et al., 2003). Continuous single-phase processes are predominant. In Europe, only $11 \%$ of the total digestion capacity is offered by two-phase systems (De Baere, 2000), probably because singlephase systems are cheaper with regards to the investment and maintenance required (MataAlvarez et al., 2000). Several advantages of two-phase systems have been reported (Cho et al., 1995; Ghosh and Klass, 1978; Llabrés-Luengo and Mata-Alvarez, 1988; O’Keefe and Chynoweth, 2000; Raynal et al., 1998; Zoetemeyer et al., 1982). While during the first phase appropriate conditions accelerate liquefaction, the second phase converts soluble matter into biogas. This allows for a more rapid and more stable process compared to single-phase systems (O'Keefe and Chynoweth, 2000). However, distinct separation between hydrolysisacidification and methanation is difficult to maintain (Cho et al., 1995; Christ, 1999; MataAlvarez et al., 2000; Raynal et al., 1998), which may eliminate the associated benefits of a twophase system (O'Keefe and Chynoweth, 2000). Phase separation appears to be more difficult for slowly hydrolysable substrates (Chanakya et al., 1992). For solid materials with slow degradability, single-phase digestion is recommended (Christ, 1999; Wechs, 1985). For easily degradable materials, a two-phase system is considered more advisable (Mata-Alvarez et al., 2000; Pavan et al., 2000). With systems in which leachate trickles through a biomass bed, phase separation may be more difficult to achieve than with stirred digesters due to lack of mixing and low ion diffusion in a non-flooded matrix (O'Keefe and Chynoweth, 2000).

In agriculture, slurry-based liquid-phase digestion is widely applied today, but digestion with elevated TS contents promises further development. Research data has been published on the digestion of crop residues, herbs and leafy biomass (Anand et al., 1991; Chanakya et al., 1993; 1997; Jewell et al., 1982; Legrand and Jewell, 1987; Liu et al., 1987; Sun et al., 1987), dairy manure (Kalia and Singh, 2001; Linke, 2000; Schäfer et al., 2005; Weizhong et al., 1999), 
pig dung (Zelter, 1978), yard waste (O'Keefe et al., 1993; Owens and Chynoweth, 1992), energy crops (Jewell et al., 1993) and various ensiled substrates (Linke and Schelle, 2001).

Batch digestion is a simpler method than continuous digestion (Ten Brummeler and Koster, 1990). In general, batch-operated solid-phase installations in agriculture have a volume of $100-150 \mathrm{~m}^{3}$ per reactor (Weiland, 2004). In what is called the percolation process, liquid is recirculated and sprinkled over the stacked material in order to initiate biogas production and encourage bacteriological activity in the decomposing biomass throughout the process.

Biological activities are limited by an inadequate supply of moisture and associated organisms and nutrients (Chen and Chynoweth, 1995). A leachate flow through a biomass bed accelerates mass transfer by adding convective transport mechanisms to molecular diffusion (Martin, 1999). Leachate recycling has been found favourable for anaerobic decomposition of landfill material (Barlaz et al., 1992; Chan et al., 2002; Mata-Alvarez and Martinez-Viturtia, 1986; Mehta et al., 2002). However, it has also been reported that acidogenesis in particular may be enhanced, which may result in the inhibition of methanogenesis (Komilis et al., 1999a). Optimal conditions for methanogens are especially important in the initial stage; therefore, low leachate recirculation rates should be chosen when initiating the process (Vavilin et al., 2002; 2003). Recirculating leachate within an already acidified cell will not correct the problem (O'Keefe and Chynoweth, 2000). The exchange of leachate between a batch of previously stabilized waste and a batch of fresh waste enhances degradation (Chugh et al., 1999; Chynoweth et al., 1992; O'Keefe et al., 1993; Suna Erses and Onay, 2003). Compaction can hinder the proper distribution of leachate (Komilis et al., 1999a). For MSW, Chen and Chynoweth (1995) found a logarithmic relationship between hydraulic conductivity and packing density.

During start-up phases, the microbial community should contain sufficient levels of methanogens to prevent digester failure (Griffin et al., 1998). The conversion of hydrolyzed organics to volatile fatty acids (VFA) will result in VFA accumulation along with a drop in $\mathrm{pH}$ if acids are not metabolized by methanogens. Methane bacteria are sensitive to $\mathrm{pH}$ (Clark and Speece, 1970), values >6.5 (Christ, 1999) or >6.8 (Chen and Hashimoto, 1996) and in general $<7.5$ are recommended. The addition of an appropriate inoculum ratio is favourable during startup (Chen and Hashimoto, 1996; Ten Brummeler and Koster, 1989), and inoculum quality is also important (Dirar and El Amin, 1988). The hypothesis has been proposed that in a bed of organic 
substrate, anaerobic digestion is initiated by seed bodies around which reaction zones gradually develop (Martin et al., 2003). When densely seeded with inoculum, the expansion of methanogenic areas into the total volume of the digester occurs quite rapidly (Martin et al., 2003; Vavilin et al., 2002). Unnecessarily high levels of inoculum lead to increased digester sizes and would therefore be undesirable (Chanakya et al., 1997).

Greater particle-substrate surface areas increase contact between micro-organisms and organic mass (Barlaz et al., 1990). The positive effects on the biodegradability after size reduction of substrate particles have been discussed by Mata-Alvarez et al. (2000); biofibre degradation may be enhanced by shearing rather than by an actual change in size distribution. However, accelerated hydrolysis and acid generation might also inhibit methanogens. Contradictory results regarding the shredding of MSW have been discussed by Komilis et al. (1999b); increased compaction was also qualified as negative.

Pre-aeration is carried out in solid-phase digestion systems to reduce the anaerobic heat requirement by using the temperature increase resulting from the composting step. Pre-aeration may also reduce acidification during start-up phases (Ten Brummeler and Koster, 1990). It has also been hypothesized that pre-composted solid substrate is more easily degradable in an anaerobic system because the aerobic treatment allows a depolymerization of complex organic fractions (Komilis et al., 1999b; Mata-Alvarez et al., 1993). However, the pool of organic material for biogasification is lower due to the fact that easily degradable components are already metabolized (O'Keefe and Chynoweth, 2000; Ten Brummeler and Koster, 1990).

The anaerobic digestibility of horse dung is documented in literature (Mandal and Mandal, 1998). Kalia and Singh (1998) observed phase separation, with fibrous horse dung floating at the top of the liquid phase, which was found unsuitable for running a continuous slurry-based digester with higher ratios of horse dung. Gas production with mixtures of horse and cattle dung was slightly poorer than with cattle dung alone.

In this study, horse dung was digested in laboratory-scale solid-phase reactors both with percolation and in flooded mode. In an initial experiment the necessary proportion of solid inoculum (pre-fermented horse dung) was determined. In a second experiment percolation and flooding were directly compared, using process water containing methanogenic bacteria. Furthermore, the dung was flooded with potable water in order to investigate the possibility of biogas production without the addition of any inoculation material. One test cell was pre-aerated 
before flooding in order to find out if an intensified aerobic phase leads to an improvement in the microbiological breakdown of the substrate structure and therefore to higher biogas production. Whether or not gasification is positively influenced by chopping the substrate was also investigated.

\section{Materials and methods}

\subsection{Reactor design and operation}

All nine reactors (Figure 1) were water-jacketed and thermostatted stainless steel cylinders (solid material content: around $50 \mathrm{~L}$; inner diameter $30 \mathrm{~cm}$ ). Leachate was collected in a liquidphase reservoir at the base. Liquid pumps (average liquid flow: $4.7 \mathrm{~L} / \mathrm{min}$ ) were set with timers to sprinkle leachate over the biomass bed automatically. Substrate temperature in the middle of the digester and at a height of $13 \mathrm{~cm}$ above the substrate ground was measured (Pt1000) and recorded twice per hour with a data logger. Biogas was collected in aluminium coated PE/PTFE-gas bags. The digesters offered the possibility to aerate the substrate. Gas from the aerated phase was sent directly to a bellows-type gas flow meter.

\subsection{Experimental configuration}

Two experimental runs with 9 test cells each were performed; Table 1 summarizes the experimental set-up.

In experiment 1 fresh material (FM) was digested with percolation in mixtures with different proportions of solid inoculum (SI): 10, 20, 30, 40, 44 and 50\% (w/w) on a TS-basis (further referred to as SI_10,SI_20,SI_30,SI_40,SI_44,SI_50). Pure solid inoculum was also digested with percolation (SI_100). Pure fresh material was digested both with percolation (FM_percol) and flooded with liquid inoculum (FM_flood).

In experiment 2 , in response to the results of experiment 1 , horse dung with $20 \%$ solid inoculum was digested with percolation in two replicates (Percol1, Perco/2). In two reactors horse dung was flooded with liquid inoculum (FloodLI1, FloodLI2); in two others with potable water (FloodPW1, FloodPW2). Chopped dung (sent twice through a compost chopper; final straw particle size around $4 \mathrm{~cm}$ ) was flooded with liquid inoculum in two replicates (ChoppLI1, ChoppL/2). In the 9th reactor (Aeration) digestion was started after pre-aeration (48 h, 160 $L$ air/h). 
For mixtures of fresh substrate and solid inoculum, fractions were first homogenized after a simplified quartering method (opposite quarters were not remixed): material was poured onto a flat surface and after intensive mixing, it was divided into quarters; then, paying special attention so as not to lose the fine material, each quarter was remixed and divided again into quarters until the desired volume was reached. The final mixture of fresh material with solid inoculum was thoroughly carried out by hand. The weights of the materials added were determined when preparing substrate mixtures and the volumes of the mixtures when filling the reactors under very low compaction by hand. At the beginning, the same amount of liquid inoculum (LI) was added to all percolated test cells until percolation (recirculation of liquid) for 15 minutes was possible in the first cell. Different amounts of potable water were added to the others until percolation was possible in all of them.

Experiment 1 was run over a period of 74 days and experiment 2 over a period of 46 days. The target temperature was $35^{\circ} \mathrm{C}$. Leachate was recirculated twice daily for 15 minutes in all reactors (percolated and flooded cells). Additionally, leachate was recirculated (15 to $20 \mathrm{~min}$ ) prior to sampling. It is assumed that this ensured an equalisation between free leachate and liquid retained in the substrate body. It is also assumed that analysing the liquid phase enabled the evaluation of the conditions in the substrate body, e.g. accumulation of inhibitory substances. Leachate was sampled periodically and analysed for $\mathrm{pH}, \mathrm{VFA}, \mathrm{NH}_{4}-\mathrm{N}$, Total Kjeldahl Nitrogen (TKN), chemical oxygen demand (COD), TS and volatile solids (VS), as was liquid at the beginning and the end of an experimental run. Solid material was sampled before and after digestion and analysed for TS and VS.

\subsection{Differentiation between methane yield and methane production (release)}

A certain amount of biogas is not released from the reactor but remains inside, filling pores of the substrate stack and empty spaces (e.g. as occurs after substrate compaction). The volume of void space above the solid residue was determined (by measuring the corresponding height), but biogas filling the substrate pores was neglected. Gas quality was assumed to be identical to the quality in the gas bag that was measured previously; thus, methane volumes remaining inside the reactors were calculated. These volumes are taken into account whenever methane yields and exploitation degrees are discussed. They are not taken into consideration when methane production is presented in cumulative form over the digestion time (methane release 
from the reactor). At full-scale, only the methane released from the reactor would be usable and not the actual yield.

\subsection{Calculation of $\mathrm{CH}_{4}$-yield from fresh material $\left(G_{F M}\right)$ in mixtures}

In mixtures with solid inoculum and/or liquid inoculum the methane yield from the component fresh material $G_{F M}$ can be derived from the total yield of the mixture if the individual yields from solid and liquid inoculum are known (assuming that the specific yields of inocula do not change in the mixture). For these calculations the total methane yield (methane released from digester plus methane remaining inside void digester spaces) was taken into account.

In experiment 1 the $\mathrm{CH}_{4}$-yield from solid inoculum was determined using reactor SI_100. In experiment 2, trials to digest solid inoculum in $5 \mathrm{~L}$ bottles failed. Therefore, this value was calculated by assuming that the solid inoculum, which was the solid residue from experiment 1 , consisted of two parts: a) material which in experiment 1 was previously solid inoculum and $b$ ) material which in experiment 1 was previously fresh material. The probable methane yield for part $a$ in experiment 2 was determined by extrapolating the data from reactor SI_100 (according to the procedure for determining the total methane potential which will be described later, also see Figure 2). It was assumed that the $\mathrm{CH}_{4}$-yield for part $b$ during experiment 2 was $90 \%$ of the difference between the total methane potential $\left(G_{p o t}\right)$ and the yield already obtained during the 74 days of experiment 1.

$\mathrm{CH}_{4}$-yield of the component liquid inoculum was determined using the equipment for the HBT method (Hohenheim biogas yield test) (Helffrich and Oechsner, 2003a; 2003b) and digesting $30 \mathrm{~mL}$ of liquid in three replicates.

\subsection{Total methane potential $\left(G_{p o t}\right)$ and exploitation degree $(q)$}

The total methane potential of horse dung (fresh material in experiment 1 ) was determined with the HBT (Helffrich and Oechsner, 2003a; 2003b). In a $100 \mathrm{~mL}$ glass syringe (flask sampler), 0.5 $\mathrm{g}$ of test substrate (dried at $60^{\circ} \mathrm{C}$ over $48 \mathrm{~h}$, ground $<1 \mathrm{~mm}$ ) and $30 \mathrm{~mL}$ inoculum (pre-digested liquid manure) were digested at $37^{\circ} \mathrm{C}$ in three replicates. The volume and methane content of the biogas produced were recorded periodically. Inoculum without substrate was digested as zero variant with three replicates as well. 
After 44 days the test was stopped. The total methane potential $G_{p o t}=G(t \rightarrow \infty)$ was calculated by extrapolation, based on a non-linear curve fit for the experimental data of the decay phase (declining gas production rate) (Figure 2). According to the biochemical degradation of solid materials in landfills (Kruse, 1994), it was assumed that gas production in the decay phase could be best described by the sum of two decay functions in the form $G(t)=a+b_{1} e^{-k_{1} t}+b_{2} e^{-k_{2} t}$ (with $G(t)$ : methane yield at time $t ; a, b_{i}, k_{i}:$ const.).

The actual methane yield depends not only on the total methane potential but also on digestion time and degradation kinetics, which is influenced by substrate characteristics (including pre-treatment) and process conditions. The exploitation degree $\mathrm{q}_{\mathrm{ti}}=\mathrm{G}_{\mathrm{FM}, \mathrm{ti}} / \mathrm{G}_{\mathrm{pot}}$ at a specific point in time $t_{i}$ was determined after calculating the methane yield from the component fresh horse dung $\mathrm{G}_{\mathrm{FM}, \mathrm{ti}}$ as described above (part 2.4.).

\subsection{Substrates}

The main substrate properties are summarized in Table 2 . Horse dung was collected from a typical horse stable with straw bedding. The proportion of straw in the manure was high. The dung for the two experiments was collected separately; in experiment 2 the proportion of faeces appeared slightly higher upon visual inspection. Pre-digested substrate as solid inoculum for experiment 1 was taken directly from the large-scale digester at this stable, where flooded horse dung was digested as a mono substrate in a one-phase, batch-operated solid-phase process in six-week cycles (with no recirculation of process water within one reactor or between different reactors during this time, and no reactor heating), as described elsewhere (Kusch and Oechsner, 2004). Liquid inoculum for experiment 1 was taken from the same digester.

The solid inoculum used in experiment 2 was the mixed solid residue from all nine reactors of experiment 1. Liquid inoculum was also gained from experiment 1: at the end of experiment 1 the liquid of all nine reactors was mixed and diluted with potable water in a 1:1ratio $(v / v)$.

\subsection{Analyses}

$\mathrm{CH}_{4}$ - and $\mathrm{CO}_{2}$-quality were determined by infrared spectroscopy (Siemens Ultramat, calibration before every reading). Gas quantity was determined with a bellows-type gas flow meter (GMT, 
reading accuracy $0.1 \mathrm{~L}$ ), calibrated to the flow of the vacuum pump ( $45 \mathrm{~L} / \mathrm{min})$. Gas volumes were corrected to norm litres $\left(L_{N}\right)$, taking into account norm pressure and norm temperature (1.013 bar, $\left.0^{\circ} \mathrm{C}\right)$.

Solid samples were analysed directly. Liquid samples were analysed either directly, within 24 hours after storage at $5^{\circ} \mathrm{C}$ or after being kept frozen at $-22^{\circ} \mathrm{C}$ (but $\mathrm{pH}$ was always measured directly from the fresh sample). TS was determined by drying the samples at $105^{\circ} \mathrm{C}$ (solid samples $48 \mathrm{~h}$, liquids $12 \mathrm{~h}$ ) and VS by incineration of the samples at $550^{\circ} \mathrm{C}$ in a muffle kiln (ground solid samples $>12 \mathrm{~h}$, liquids approx. $8 \mathrm{~h}$ ). The analytical methods used for COD, $\mathrm{pH}$, $\mathrm{NH}_{4}-\mathrm{N}$ and TKN conformed to DIN/EN-standards (DEV, 2004). VFA represent the sum of acetic, propionic, butyric, valeric and caproic acids and were measured by gas chromatography (GC) as follows: $1 \mu \mathrm{L}$ supernatant ( $1 \mathrm{~g}$ sample, acidified with formic acid $_{\text {conc }}$, diluted 1:10, $15 \mathrm{~min}$ centrifuged at $16110 \times$ g) was injected into a Varian CP-3800 GC (capillary column SGE BP 21, $25 \mathrm{~m} \times 0.32 \mathrm{~mm}, 0.25 \mu \mathrm{m}$ film; helium carrier gas at $40 \mathrm{~mL} / \mathrm{min}$ in split 1:10; column temperature sequence: $40^{\circ} \mathrm{C}$ for $2 \mathrm{~min}$, ramp of $15^{\circ} \mathrm{C} / \mathrm{min}, 125^{\circ} \mathrm{C}$ for $1.5 \mathrm{~min}$, ramp of $25^{\circ} \mathrm{C} / \mathrm{min}$, $180^{\circ} \mathrm{C}$ for $5 \mathrm{~min}$; injector temperature $\left.180^{\circ} \mathrm{C}\right)$, equipped with a flame ionization detector $\left(280^{\circ} \mathrm{C}\right)$.

\section{Results and discussion}

\subsection{Total methane potential}

The total methane potential $G_{\text {pot }}$ of the fresh horse dung used in experiment 1 was determined as $277.0 \mathrm{~L}_{\mathrm{N}} \mathrm{CH}_{4} / \mathrm{kg} \mathrm{VS}$ added (Figure 3). This is lower than the methane potential reported for wheat straw by Tong et al. (1990) of 302 or $333 \mathrm{~L}_{\mathrm{N}} \mathrm{CH}_{4} / \mathrm{kg} \mathrm{VS}$ added (two straw types, finely milled, 60 days in optimized batch test). Møller et al. (2004) found final methane yields of $195 L_{N}$ $\mathrm{CH}_{4} / \mathrm{kg} \mathrm{VS}_{\text {added }}$ for wheat straw (cut to $1 \mathrm{~mm}, 110$ days), but quoted values of up to $241 \mathrm{~L}$ $\mathrm{CH}_{4} / \mathrm{kg} \mathrm{VS}_{\text {added }}$ from literature.

\subsection{Ratio of solid inoculum}

Among the percolated reactors in experiment 1, SI_20 had the highest methane production after 28 days (Figure 4), but differences were only marginal within group SI_10/20/30/40. This is due to the very high $\mathrm{CH}_{4}$-yield of the solid inoculum. After 28,42 and 74 days, the methane productions from SI_100 were 122.4, 159.2 and $188.9 \mathrm{~L}_{\mathrm{N}} \mathrm{CH}_{4} / \mathrm{kg} \mathrm{VS}_{\text {added,SI }}$, respectively; these values are close to the amounts of methane produced by reactors containing fresh material and 
indicate that digestion quality in the full-scale plant was poor. Indeed, severe problems, especially concerning temperature maintenance, were observed during the winter months when the materials were collected.

Figure 4 also shows the volumetric methane production. It should be kept in mind, however, that the contribution from solid inoculum was very high, which means that energy density in all test cells was quite similar. In 42 days, up to 10.4 and $10.5 \mathrm{~L}_{\mathrm{N}} \mathrm{CH}_{4} / \mathrm{L}$ (SI_10 and SI_20) were produced with percolation.

FM_percol (no solid inoculum) had lower biogas production during the first 42 days. This option would be favourable only for longer digestion times. Inhibition during the start-up phase becomes less important with longer digestion times; consequently, the methane production of FM_percol was highest after 74 days (among percolated cells).

It was concluded that a proportion of $10-20 \%$ solid inoculum would be suitable for digestion of horse dung with percolation in six-week cycles. In the present study, despite the poor quality of the inoculum, 10\% was sufficient. As the quality of horse dung may differ with regard to its contents, age, and storage prior to being digested, a higher proportion of $20 \%$ inoculum may be chosen in order to avoid process failure in full-scale applications.

Methane production in FM_flood was rapid, with no evident inhibition. It was, therefore, concluded that in the flooded mode no addition of solid inoculum would be necessary.

\subsection{Comparison of flooding and percolation}

Within 42 days Percol1/2 produced (released) $147.3 \mathrm{~L}_{N} \mathrm{CH}_{4} / \mathrm{kg} \mathrm{VS}$ added,mixture (mean of both replicates) and FloodLI1/2 $160.9 \mathrm{~L}_{\mathrm{N}} \mathrm{CH}_{4} / \mathrm{kg}$ VS added,mixture (Figure 5). Although methane production from the flooded reactors was higher, the actual $\mathrm{CH}_{4}$-yield from the component fresh horse dung $\left(\mathrm{G}_{\mathrm{FM}, 42}\right)$ was similar (Table 3): 173.8 and $171.5 \mathrm{~L}_{\mathrm{N}} \mathrm{CH}_{4} / \mathrm{kg} V S_{\text {added,FM }}$ for Percol1/2 and FloodLI1/2, respectively. This demonstrated that the digestibility of horse dung was comparable in the flooded and in the percolated mode.

Methane production per volume solid substrate, however, was higher with flooding, as no solid inoculum was necessary. Flooded reactors (FloodLI1/2) produced $11.4 \mathrm{~L}_{\mathrm{N}} \mathrm{CH}_{4} / \mathrm{L}$ and percolated cells (Percol1/2) 8.4 $\mathrm{L}_{\mathrm{N}} \mathrm{CH}_{4} / \mathrm{L}$ in 42 days. In experiment 1 the flooded cell (FM_flood) produced 11.7 $\mathrm{L}_{\mathrm{N}} \mathrm{CH}_{4} / \mathrm{L}$, while percolated ones generated up to $10.5 \mathrm{~L}_{\mathrm{N}} \mathrm{CH}_{4} / \mathrm{L}$ (SI_20) in 42 days. Flooding therefore increased volumetric methane production by a factor of 1.11 in 
experiment 1 , but by a factor of 1.35 in experiment 2 . This was due to the lower specific $\mathrm{CH}_{4}$ yield from the component solid inoculum in experiment 2 compared to experiment 1 (a factor of 0.41). Methane yield $\mathrm{G}_{\mathrm{FM}, 42}$ from the component fresh material itself was similar in both experiments (Table 3: 173.8 and $174.7 \mathrm{~L}_{\mathrm{N}} \mathrm{CH}_{4} / \mathrm{kg}$ VS added,FM for Percol1/2 and SI_20, respectively). This showed that methane production in the percolated process was significantly influenced by the amount of solid inoculum added and also by the specific methane yield from the inoculum (very low in experiment 2 due to the long digestion in experiment 1 ; this would not be the case in a full-scale application).

The $\mathrm{pH}$ remained in a favourable range both in Percol1/2 and in FloodLI1/2 (Figure 6). Leachate COD was higher in Percol1/2 than in FloodLI1/2, with a more marked difference during the first weeks. In Percol1/2, up to 3810 ppm of VFA appeared on day 7, with up to 3210 ppm propionate (Figure 7). In FloodLI1/2, up to 2660 ppm of VFA with a maximum of $1560 \mathrm{ppm}$ of propionate was measured. This indicated that percolated digesters may be more susceptible to VFA accumulation. In this experiment, however, no inhibition appeared; in both cell types VFA were completely degraded before day 18 .

\subsection{Flooding with potable water}

Methane production from FloodPW1/2 was $151.2 \mathrm{~L}_{\mathrm{N}} \mathrm{CH}_{4} / \mathrm{kg}$ VS added,mixture=FM after 42 days (Figure 5). This was $94 \%$ of the amount produced by FloodLI1/2, though production was considerably lower during the first 10 days. The inhibited performance during the first few weeks corresponded to a pH decrease to around 6.1 on day 7; afterwards, the $\mathrm{pH}$ gradually increased to 7.0 on day 34 (Figure 6). Although the optimum pH range for methanogens (6.8 to 7.5 ) was reached only on day 18 , the overall digester stability was good. The microbiological removal of VFA was complete by day 25 . This demonstrated that the microbiological population adapted well to this environment and that digestion of horse dung was possible without any addition of inoculum.

\subsection{Chopping and pre-aeration}

Cumulative methane production of ChoppLI1/2 was $180.1 \mathrm{~L}_{\mathrm{N}} \mathrm{CH}_{4} / \mathrm{kg} \mathrm{VS}_{\text {added,mixture }}$ after 42 days. Methanisation was considerably enhanced during the first weeks: compared to FloodLI1/2, methane production increased by $22 \%, 18 \%$ and $12 \%$ after 15,21 and 42 days respectively. 
Anaerobic digestion of solid substrates is often rate-limited by the hydrolysis step (Christ, 1999), and mechanical pre-treatment can therefore improve digester performance (Mata-Alvarez et al. 2000). In the digestion of lignocellulosic material, enzymes must break the lignin barrier in order to gain access to the holocellulose; therefore, the reaction rate is directly related to the surface to which hydrolyzing bacteria can attach (Tong et al., 1990). Increased particle surface area enhances biodegradation but does not affect ultimate methane yield. Consequently, in the present experiment differences between chopped and unchopped substrate gradually became smaller with longer digestion times.

Pre-aeration did not enhance process kinetics. The test cell with pre-aerated horse dung produced $131.4 \mathrm{~L}_{\mathrm{N}} \mathrm{CH}_{4} / \mathrm{kg} \mathrm{VS}_{\text {added,mixture }}$ in 42 days, which is $18 \%$ lower than FloodLI1/2.

\subsection{Methane yield from component fresh horse dung $\left(G_{F M}\right)$ and exploitation degree (q)}

Table 3 summarizes methane yields $\mathrm{G}_{\mathrm{FM}}$ from the component fresh horse dung in experiments 1 and 2. They were similar for all test cells in which no inhibition occurred and material without pre-treatment was used. Mean $\mathrm{G}_{\mathrm{FM}, 42}$ (42 days) was $169.3 \pm 3.4 \mathrm{~L}_{\mathrm{N}} \mathrm{CH}_{4} / \mathrm{kg} \mathrm{VS}_{\text {added,FM }}$ (mean \pm $\mathrm{SD}, \mathrm{n}=5$, SI_10/20/30/40/FM_flood) in experiment 1 and $172.6 \pm 2.7 \mathrm{~L}_{\mathrm{N}} \mathrm{CH}_{4} / \mathrm{kg}$ VS $\mathrm{S}_{\text {added,FM }}(\mathrm{n}=4$, Percol/FloodLI/1/2) in experiment 2, and was therefore not significantly different between the two runs ( $p=0.16$ in unpaired, two-tailed Student's t-test). For both experimental runs mean $\mathrm{G}_{\mathrm{FM}, 42}$ was $170.8 \pm 3.4 \mathrm{~L}_{\mathrm{N}} \mathrm{CH}_{4} / \mathrm{kg} \mathrm{VS}_{\text {added,FM }}(\mathrm{n}=9$, abovementioned cells). The corresponding exploitation degree $\mathrm{q}_{42}$ from the total methane potential $\mathrm{G}_{\mathrm{pot}}$ was 0.62 , which means that $62 \%$ of $\mathrm{G}_{\mathrm{pot}}$ was converted in 42 days.

In 74 days, $74 \%$ of the total methane potential was converted $\left(q_{74}=0.74 ; \mathrm{G}_{\mathrm{FM}, 74}=205.5 \pm\right.$ 3.1 $\mathrm{L}_{\mathrm{N}} \mathrm{CH}_{4} / \mathrm{kg} V \mathrm{~S}_{\text {added,FM; }} \mathrm{n}=6$, FM_percol/flood/SM_10/20/30/40). The proportion $\mathrm{q}_{42} / \mathrm{q}_{74}$ was 0.83 , which means that $83 \%$ of the yield in 74 days was converted during the first 42 days. This is more than in experiments with pig dung in solid-phase digestion with percolation conducted by Zelter (1978), in which 75\% of the ten week yield was produced in the first six weeks.

Mean $\mathrm{G}_{\mathrm{FM}, 28}$ was $144.6 \pm 1.8 \mathrm{~L}_{\mathrm{N}} \mathrm{CH}_{4} / \mathrm{kg}$ VS added,FM $(\mathrm{n}=4$, SI_20/30/40/FM_flood). Only $52 \%$ of the total methane potential was obtained in 28 days $\left(q_{28}=0.52\right)$.

Chopping enhanced biodegradability to $\mathrm{q}_{42}=0.69$ and to mean $\mathrm{G}_{\mathrm{FM}, 42}=192.4 \mathrm{~L}_{\mathrm{N}}$ $\mathrm{CH}_{4} / \mathrm{kg} \mathrm{VS}$ added,FM $(C h o p p L I 1 / 2)$. Pre-aeration resulted in an exploitation degree of $\mathrm{q}_{42}=0.51$. 
Comparing this to $\mathrm{q}_{42}=0.62$ of the substrate without pre-treatment, it was concluded that $11 \%$ of $\mathrm{G}_{\text {pot }}$ was lost through aeration.

\subsection{VS removal}

In Table 4, VS removal within 46 days is given for the solid phase (SP) and for the complete system (solid and liquid phase, SP + LP) because the two values differed (for calculation procedure see footnotes to Table 4). As considerable amounts of VS were found in the liquid phase, removal in SP was higher than the degradation in the system (SP + LP). The difference was more obvious with higher liquid volumes in the system. The liquid contained up to $19 \%$ of the final VS in the flooded system (ChoppLI1) and around 4\% of the final VS in the percolated process.

In FloodLI1/2, the initial VS of the solid phase was reduced by $49 \%$, and $44 \%$ of the total initial VS (SP + LP) was actually degraded. In the pre-aerated test cell, $46 \%$ of the total VS left the system during the experiment. This shows that the overall degradation of VS was comparable to the flooding without pre-aeration (FloodLI1/2), although energy recovery was lower. In Percol1/2, $40 \%$ of the VS in the solid phase was hydrolyzed and most of it ( $38 \%$ of the initial VS in the system) was metabolized by the methanogenic population. VS removal was lower with percolation than with flooding, which reflects poorer degradability of the organic material due to the addition of solid inoculum.

Mean methane production per kg VS removed was $397.0 \pm 17.6 \mathrm{~L}_{N} \mathrm{CH}_{4} / \mathrm{kg}$ VS $\mathrm{S}_{\text {removed }}(\mathrm{n}=8$, Percol/FloodLI/PW/ChoppLI1/2), but the high standard deviation hinders further interpretation. The effect of lost VS when taking leachate samples was not considered in this study. Neither were various yet small amounts of material lost while emptying the reactors at the end of the experiment.

\subsection{Further results}

Biogas methane content of all reactors exceeded 50\% after one week, although Percol1/2, Aeration and FloodPW1/2 demonstrated slightly poorer performance during the first few days (Figure 8). Methane contents of up to $60 \%$ were measured, with chopped substrate of up to $63 \%$. All reactors reached a final gas quality of $52.5-53.5 \% \mathrm{CH}_{4}$. Mean methane content over the whole digestion time (46 days) ranged from 51.1-53.5\% (Table 4). 
Nitrogen accumulation did not reach inhibitory levels, final concentrations in the liquid phase were $<520 \mathrm{mg} / \mathrm{L} \mathrm{NH}_{4}-\mathrm{N}$ and $<1130 \mathrm{mg} / \mathrm{L}$ TKN (Table 4). Poggi-Varaldo et al. (1997) determined a critical ammonia concentration of $2800 \mathrm{mg} / \mathrm{kg} \mathrm{NH}_{4}-\mathrm{N}$ (MSW, mesophilic digestion at high TS content) and quoted from literature higher tolerable concentrations in liquid- or slurrymode digestion. With better adapted bacteria, Weiland (1993) observed stable digestion of agro-industrial residues in the presence of $5000 \mathrm{mg} / \mathrm{L} \mathrm{NH}_{4}-\mathrm{N}$.

Temperatures in the test cells of experiment 2 (Figure 9) were close to target temperature $\left(35^{\circ} \mathrm{C}\right)$; differences of more than $1^{\circ} \mathrm{C}$ (median) occurred only in the middle of Percol1/2. In this study the replicates were positioned directly beside one another (no randomized distribution, which was not optimal). Percol1/2 were closest to the thermostat and so their position in terms of heat supply was optimal. The results indicate that problems with temperature maintenance may occur in percolated digesters. It may be assumed that, compared to flooded digesters, thermal energy transport is more difficult as pores inside the substrate stack are partly filled with gas and not with liquid.

\section{Conclusions}

Horse dung with straw was shown to be digestible as a mono substrate in batch-operated solidphase digestion. Both in the percolation and in the flooded process, the specific methane yield of the fresh substrate was found to be around $170 \mathrm{~L}_{N} \mathrm{CH}_{4} / \mathrm{kg} \mathrm{VS}$ added,FM in six weeks under optimal conditions and without pre-treatment (aside from the addition of inoculum). Compared to percolation, flooding itself did not enhance degradability of horse dung within six weeks. However, the volumetric methane production was higher in the flooded system as no solid inoculum had to be added. The results show that percolation and flooding can both achieve the same methane yield per kg VS of fresh horse dung added, but this requires larger reactor volumes in the percolated system.

In the percolation process a rapid start-up was ensured by the addition of $10-20 \%$ (w/w on TS-basis) pre-fermented horse dung as solid inoculum. Up to $10.5 \mathrm{~L} \mathrm{CH}_{4} / \mathrm{L}_{\text {solid substrate }}$ were produced in six weeks with percolation and up to $11.7 \mathrm{~L} \mathrm{CH}_{4} / \mathrm{L}$ with flooding. Assuming a mean $\mathrm{CH}_{4}$-content of $50 \%, 21 \mathrm{~m}^{3}$ biogas $/ \mathrm{m}^{3}$ could be expected with percolation and $23 \mathrm{~m}^{3}$ biogas $/ \mathrm{m}^{3}$ would be probable in the flooded process in six-week cycles with horse dung that did not 
undergo any pre-treatment. Altered bulk density in full-scale applications may influence the result, a factor which could not be examined in this work.

The total methane potential of the horse dung was determined as $277 \mathrm{~L}_{\mathrm{N}} \mathrm{CH}_{4} / \mathrm{kg}$ $\mathrm{VS}_{\text {added,FM. }}$. Of this, only $52 \%$ was converted in four weeks, $62 \%$ in six weeks and $74 \%$ in 74 days when using substrate without pre-treatment. Chopping the substrate with a compost chopper accelerated biogasification significantly. Aeration as a pre-digestion treatment failed to be successful. It resulted in a lower biogas yield with no enhancement of the process kinetics.

\section{Acknowledgements}

This study was conducted as part of a research project financed by the Ministry for Nutrition and Agriculture of Baden-Württemberg, Germany.

\section{References}

Anand, V., Chanakya, H.N., Rajan, M.G.C., 1991. Solid phase fermentation of leaf biomass to biogas. Resources, Conservation and Recycling 6, 23-33.

Barlaz, M.A., Ham, R.K., Schaefer, D.M., 1990. Methane production from municipal refuse: a review of enhancement techniques and microbial dynamics. CRC Critical Reviews in Environmental Control 19, 557-584.

Barlaz, M.A., Ham, R.K., Schaefer, D.M., 1992. Microbial, chemical and methane production characteristics of anaerobically decomposed refuse with and without leachate recycling. Waste Manage. Res. 10, 257-267.

Bolzonella, D., Innocenti, L., Pavan, P., Traverso, P., Cecchi, F., 2003. Semi-dry thermophilic anaerobic digestion of the organic fraction of municipal solid waste: focusing on the start-up phase. Bioresource Technol. 86, 123-129.

Chan, G.Y.S., Chu, L.M., Wong, M.H., 2002. Effects of leachate recirculation on biogas production from landfill co-disposal of municipal solid waste, sewage sludge and marine sediment. Environmental Pollution 118, 393-399.

Chanakya, H.N., Borgaonkar, S., Rajan, M.G.C., Wahi, M., 1992. Two-phase anaerobic digestion of water hyacinth or urban garbage. Bioresource Technol. 42, 123-131.

Chanakya, H.N., Borgaonkar, S., Meena, G., Jagadish, K.S., 1993. Solid-phase biogas production with garbage or water hyacinth. Bioresource Technol. 46, 227-231.

Chanakya, H.N., Venkatsubramaniyam, R., Modak, J., 1997. Fermentation and methanogenic characteristics of leafy biomass feedstocks in a solid phase biogas fermentor. Bioresource Technol. 62, 71-78.

Chen, T.-H., Chynoweth, D.P., 1995. Hydraulic conductivity of compacted municipal solid waste. Bioresource Technol. 51, 205-212.

Chen, T.-H., Hashimoto, A.G., 1996. Effects of $\mathrm{pH}$ and substrate:inoculum ratio on batch methane fermentation. Bioresource Technol. 56, 179-186. 
Cho, J.K., Park, S.C., Chang, H.N., 1995. Biochemical methane potential and solid state anaerobic digestion of Korean food wastes. Bioresource Technol. 52, 245-253.

Christ, O., 1999. Leistungscharakteristik der ein- und zweistufigen thermophilen und mesophilen Vergärung von Bioabfällen, Technische Universität München, Berichte aus Wassergüte- und Abfallwirtschaft, vol. 148.

Chugh, S., Chynoweth, D.P., Clarke, W., Pullammanappallil, P., Rudolph, V., 1999. Degradation of unsorted municipal solid waste by a leach-bed process. Bioresource Technol. 69, 103-115.

Chynoweth, D.P., Owens, J., O'Keefe, D., Earle, J.F.K., Bosch, G., Legrand, R., 1992.

Sequential batch anaerobic composting of the organic fraction of municipal solid waste. Wat. Sci. Technol. 25 (7), 327-339.

Clark, R.H., Speece, R.E., 1970. The pH tolerance of anaerobic digestion. In: Jenkins, S.H. (Ed.), Advances in Water Pollution Research. Proc. 5th Int. Conf. of Water Pollution Research in San Francisco, Pergamon Press, pp. II-27, 1-14.

De Baere, L., 2000. Anaerobic digestion of solid waste: state of the art. Wat. Sci. Technol. 41 (3), 283-290.

DEV, 2004. Deutsche Einheitsverfahren zur Wasser-, Abwasser- und Schlamm-Untersuchung, loose-leaf edition, Wasserchemische Gesellschaft (Ed.), Wiley-VCH.

Dirar, H.A., El Amin, H.B., 1988. Methane fermentation of water hyacinth: effect of solids concentration and inoculum source. Mircen Journal 4, 299-312.

Ghosh, S., Klass, D.L., 1978. Two-phase anaerobic digestion. Process Biochemistry 13, 15-24.

Griffin, M.E., McMahon, K.D., Mackie, R.I., Raskin, L., 1998. Methanogenic population dynamics during start-up of anaerobic digesters treating municipal solid waste and biosolids. Biotechnol. Bioengng. 57, 342-355.

Helffrich, D., Oechsner, H., 2003a. Hohenheimer Biogasertragstest. Agrartechnische Forschung 9, 27-30.

Helffrich, D., Oechsner, H., 2003b. The Hohenheim biogas yield test. Landtechnik 58 (English version), 148-149.

Jewell, W.J., Dell'Orto, S., Fanfoni, K.J., Fast, S.J., Gotting, E.J., Jackson, D.A., Kabrick, R.M., 1982. Agricultural and high strength wastes. In: Hughes, D.E., Stafford, D.A., Wheatley, B.I., Baader, W., Lettinga, G., Nyns, E.J., Verstraete, W., Wentworth, R.L. (Eds.), Anaerobic Digestion 1981. Proc. 2nd Int. Symp. on Anaerobic Digestion in Travemünde, Elsevier Biomedical Press, Amsterdam, pp. 151-168.

Jewell, W.J., Cummings, R.J., Richards, B.K., 1993. Methane fermentation of energy crops: Maximum conversion kinetics and in situ biogas purification. Biomass Bioenergy 5, 261-278.

Kalia, A.K., Singh, S.P., 1998. Horse dung as a partial substitute for cattle dung for operating family-size biogas plants in a hilly region. Bioresource Technol. 64, 63-66.

Kalia, A.K., Singh, S.P., 2001. Effect of mixing digested slurry on the rate of biogas production from dairy manure in batch fermenter. Energy Sources 23, 711-715.

Komilis, D.P., Ham, R.K., Stegmann, R., 1999a. The effect of landfill design and operation practices on waste degradation behavior: a review. Waste Manage. Res. 17, 20-26.

Komilis, D.P., Ham, R.K., Stegmann, R., 1999b. The effect of municipal solid waste pretreatment on landfill behavior: a literature review. Waste Manage. Res. 17, 10-19.

Kruse, K., 1994. Langfristiges Emissionsgeschehen von Siedlungsabfalldeponien, Technische Universität Braunschweig, Institut für Siedlungswasserwirtschaft, vol. 54. 
Kusch, S., Oechsner, H., 2004. Vergärung landwirtschaftlicher Substrate in Feststofffermentern, in: FNR (Ed.), Trockenfermentation - Evaluierung des Forschungs- und Entwicklungsbedarfs. Gülzower Fachgespräche 23, pp. 105-113.

Legrand, R., Jewell, W.J., 1987. Continuous anaerobic digestion of high solids biomass: modeling and experiments, in: Klass, D.L. (Ed.), Energy from biomass and wastes X. Institute of Gas Technology, Chicago, Elsevier Applied Science Publishers, London, UK, pp. 1077-1094.

Linke, B., 2000. Trockenvergärung - Ergebnisse über ein einfaches Satz-Verfahren im kleintechnischen Maßstab, in: Biogas - Mobilisierung der Energiereserve aus der Landwirtschaft. Proc. symp. in Schwäbisch Hall, pp. 71-79.

Linke, B., Schelle, H., 2001. Biogaserzeugung durch Nass- und Trockenfermentation, in: Mit Biogas vom Landwirt zum Energiewirt. Proc. 13th Energie-Seminar Prignitz.

Liu, K., Sun, G., Wu, X., Wu, Y., 1987. Research and application of technology for dry-wet biogas fermentation. Biological Wastes 20, 303-308.

Llabrés-Luengo, P., Mata-Alvarez, J., 1988. The hydrolytic step in a dry digestion system. Biological Wastes 23, 25-37.

Mandal, T., Mandal, N.K., 1998. Biomethanation of some waste materials with pure metallic magnesium catalyst: improved biogas yields. Energy Conversion and Management 39, 11771179.

Martin, D.J., 1999. Mass transfer limitations in solid-state digestion. Biotechnol. Letters 21, 809814.

Martin, D.J., Potts, L.G.A., Heslop, V.A., 2003. Reaction mechanisms in solid-state anaerobic digestion: I. The reaction front hypothesis. Process Safety and Environmental Protection, Transactions IChemE 81 (B3), 171-179.

Mata-Alvarez, J., Martinez-Viturtia, A., 1986. Laboratory simulation of municipal solid waste fermentation with leachate recycle. J. Chem. Technol. Biotechnol. 36, 547-556.

Mata-Alvarez, J., Cecchi, F., Pavan, P., Bassetti, A., 1993. Semi-dry thermophilic anaerobic digestion of fresh and pre-composted organic fraction of municipal solid waste (MSW): digester performance. Wat. Sci. Technol. 27 (2), 87-96.

Mata-Alvarez, J., Macé, S., Llabrés, P., 2000. Anaerobic digestion of organic solid wastes. An overview of research achievements and perspectives. Bioresource Technol. 74, 3-16.

Mehta, R., Barlaz, M.A., Yazdani, R., Augenstein, D., Bryars, M., Sinderson, L., 2002. Refuse decomposition in the presence and absence of leachate recirculation. J. Envir. Engrg. 128, 228236.

Møller, H., Sommer, S., Ahring, B., 2004. Methane productivity of manure, straw and solid fractions of manure. Biomass Bioenergy 26, 485-495.

O'Keefe, D.M., Chynoweth, D.P., Barkdoll, A.W., Nordstedt, R.A., Owens, J.M., Sifontes, J., 1993. Sequential batch anaerobic composting of municipal solid waste (MSW) and yard waste. Wat. Sci. Technol. 27 (2), 77-86.

O'Keefe, D.M., Chynoweth, D.P., 2000. Influence of phase separation, leachate recycle and aeration on treatment of municipal solid waste in simulated landfill cells. Bioresource Technol. $72,55-66$.

Owens, J.M., Chynoweth, D.P., 1992. Biochemical methane potential of municipal solid waste (MSW) components, in: Cecchi, F., Mata-Alvarez, J., Pohland, F.G. (Eds.), Anaerobic digestion of solid waste. Proc. Int. Symp. on Anaerobic Digestion of Solid Waste in Venice, Pergamon Press, pp. 1-14. 
Pavan, P., Battistoni, P., Cecchi, F., Mata-Alvarez, J., 2000. Two-phase anaerobic digestion of source sorted OFMSW (organic fraction of municipal solid waste): performance and kinetic study. Wat. Sci. Technol. 41 (3), 111-118.

Poggi-Varaldo, H.M., Rodriguez-Vazquez, R., Fernandez-Villagomez, G., Esparza-Garcia, F., 1997. Inhibition of mesophilic solid-substrate anaerobic digestion by ammonia nitrogen. Appl. Microbiol. Biotechnol. 47, 284-291.

Raynal, J., Delgenès, J.P., Moletta, R., 1998. Two-phase anaerobic digestion of solid wastes by a multiple liquefaction reactors process. Bioresource Technol. 65, 97-103.

Schäfer, W., Evers, L., Lehto, M., Sorvala, S., Teye, F., Granstedt, A., 2005. Nutrient balance of a two-phase solid manure biogas plant. In: Stenberg, M., Nilsson, H., Brynjolfsson, R., Kapuinen, P., Morken, J., Birkmose, T.S. (Eds.), Manure - an agronomic and environmental challenge, Proc. NJF seminar no. 372 in Skurup/Sweden, NJF Report 1 (2), pp. 45-48.

Sun, G., Wu, Y., Sha, S., Liu, K., 1987. Dry digestion of crop wastes: Studies on dry anaerobic digestion with agricultural wastes. Biological Wastes 20, 291-302.

Suna Erses, A., Onay, T.T., 2003. Accelerated landfill waste decomposition by external leachate recirculation from an old landfill cell. Wat. Sci. Technol. 47 (12), 215-222.

Ten Brummeler, E., Koster, I.W., 1989. The effect of several pH control chemicals on the dry batch digestion of the organic fraction of municipal solid waste. Resources, Conservation and Recycling 3, 19-32.

Ten Brummeler, E., Koster, I.W., 1990. Enhancement of dry anaerobic batch digestion of the organic fraction of municipal solid waste by an aerobic pretreatment step. Biological Wastes 31, 199-210.

Tong, X., Smith, L.H., McCarty, P.L., 1990. Methane fermentation of selected lignocellulosic materials. Biomass 21, 239-255.

Vavilin, V.A., Shchelkanov, M.Y., Rytov, S.V., 2002. Effect of mass transfer on concentration wave propagation during anaerobic digestion of solid waste. Water Research 36, 2405-2409.

Vavilin, V.A., Rytov, S.V., Lokshina, L.Y., Pavlostathis, S.G., Barlaz, M.A., 2003. Distributed model of solid waste anaerobic digestion - Effects of leachate recirculation and $\mathrm{pH}$ adjustment. Biotechnol. Bioengng. 81, 66-73.

Wechs, F., 1985. Ein Beitrag zur zweistufigen anaeroben Klärschlammstabilisierung, Technische Universität München, Berichte aus Wassergüte und Gesundheitsingenieurwesen, vol. 53.

Weiland, P., 1993. One- and two-step anaerobic digestion of solid agroindustrial residues. Wat. Sci. Technol. 27 (2), 145-151.

Weiland, P., 2004. Stand der Technik bei der Trockenfermentation - Zukunftsperspektiven. In: FNR (Ed.), Trockenfermentation - Evaluierung des Forschungs- und Entwicklungsbedarfs. Gülzower Fachgespräche 23, pp. 23-35.

Weizhong, J., Kitamura, Y., Jia, J., Takeyama, K., 1999. Development of the dry methane fermentation system for livestock manure - experimental study on rotational drum fermentation. Proc. 99th Int. Conf. on Agricultural Engineering in Beijing, pp. III-51 to III-55.

Witty, W., Märkl, H., 1985. Reaktionskinetische Aspekte der Methangärung am Beispiel der Vergärung von Penicillin-Mycel. Chem.-Ing.-Tech. 57, 802-803.

Zelter, S.Z., 1978. Fermentation methanique en discontinu des dechets agricoles. Final report of a research project, Institut National de la Recherche Agronomique, Paris, France. 
Zoetemeyer, R.J., Arnoldy, P., Cohen, A., Boelhouwer, C., 1982. Influence of temperature on the anaerobic acidification of glucose in a mixed culture forming part of a two-stage digestion process. Water Research 16, 313-321. 
Table 1

Experimental set-up (FM: fresh material, SI: solid inoculum, LI: liquid inoculum, PW: potable water)

\begin{tabular}{|c|c|c|c|c|c|}
\hline & \multirow[t]{2}{*}{ description } & FM & $\mathrm{SI}$ & $\mathrm{LI}$ & PW \\
\hline & & $\mathrm{kg}$ & $\mathrm{kg}$ & $\mathrm{L}$ & $\mathrm{L}$ \\
\hline \multicolumn{6}{|c|}{ experiment 1} \\
\hline FM_percol & FM, percolated & 7.32 & - & 6.0 & 4.5 \\
\hline SI_10 & $\mathrm{FM}+9.9 \%$ SI, percolated $\left.{ }^{\star}\right)$ & 7.18 & 1.79 & 6.0 & 3.5 \\
\hline SI_20 & FM + 19.8\% SI, percolated ${ }^{*}$ & 6.30 & 3.50 & 6.0 & 3.5 \\
\hline SI_30 & $\mathrm{FM}+30.0 \% \mathrm{SI}$, percolated ${ }^{*}$ & 5.39 & 5.15 & 6.0 & 3.0 \\
\hline SI_40 & $\mathrm{FM}+39.9 \% \mathrm{SI}$, percolated $\left.^{*}\right)$ & 4.55 & 6.76 & 6.0 & 3.0 \\
\hline SI_44 & $\mathrm{FM}+44.3 \% \mathrm{SI}$, percolated $\left.{ }^{\star}\right)$ & 5.25 & 9.32 & 6.0 & 2.5 \\
\hline SI_50 & $\mathrm{FM}+50.0 \% \mathrm{SI}$, percolated $\left.{ }^{\star}\right)$ & 3.72 & 8.29 & 6.0 & 1.0 \\
\hline SI_100 & SI, percolated & - & 16.24 & 6.0 & - \\
\hline FM_flood & FM, flooded with LI & 8.71 & - & 37.0 & - \\
\hline \multicolumn{6}{|c|}{ experiment 2} \\
\hline Percol1 & $\mathrm{FM}+20.7 \%$ SI, percolated $\left.{ }^{*}\right)$ & 6.30 & 3.70 & 5.0 & 3.0 \\
\hline Percol2 & $\mathrm{FM}+20.7 \% \mathrm{SI}$, percolated $\left.^{\star}\right)$ & 6.30 & 3.65 & 5.0 & 3.0 \\
\hline FloodLI1 & FM, flooded with LI & 11.73 & - & 36.0 & - \\
\hline FloodLI2 & FM, flooded with LI & 10.78 & - & 36.0 & - \\
\hline FloodPW1 & FM, flooded with PW & 9.41 & - & - & 37.0 \\
\hline FloodPW2 & FM, flooded with PW & 9.52 & - & - & 37.0 \\
\hline ChoppLI1 & chopped FM, flooded with LI & 11.20 & - & 37.0 & - \\
\hline ChoppLI2 & chopped FM, flooded with LI & 11.06 & - & 37.0 & - \\
\hline Aeration & $\begin{array}{l}\mathrm{FM}+2 \mathrm{~L} \mathrm{PW} \text {, aerated for } 48 \mathrm{~h} \text {, } \\
\text { then flooded with } \mathrm{LI}\end{array}$ & 10.29 & - & 26.0 & 2.0 \\
\hline
\end{tabular}

${ }^{*}$ mixtures $\mathrm{FM}+\mathrm{SI}$ are in $\%$ w/w on a TS-basis: $\left(\mathrm{kg} \mathrm{TS} \mathrm{SI}_{\mathrm{I}}\right) /\left(\mathrm{kg} \mathrm{TS} \mathrm{TFM}_{\mathrm{FM}}+\mathrm{kg} \mathrm{TS} \mathrm{SI}^{\star}\right) 100 \%$

Table 2

Material characterization

\begin{tabular}{lcccc}
\hline & \multirow{2}{*}{ TS } & & \multicolumn{2}{c}{ VS } \\
\cline { 2 - 2 } \cline { 5 - 5 } \% wet w & & \% TS & \% wet w \\
\hline experiment 1 & & & \\
fresh substrate & 38.0 & & 89.2 & 33.9 \\
solid inoculum & 17.0 & & 81.4 & 13.8 \\
liquid inoculum & 2.2 & & & 0.8 \\
& & & & \\
experiment 2 & & & & \\
fresh substrate & 32.2 & & 85.8 & 27.6 \\
solid inoculum & 14.4 & & 75.2 & 10.8 \\
liquid inoculum & 1.2 & & 0.6 \\
\hline
\end{tabular}


Table 3

Methane yield from component fresh material $\left(G_{F M}\right)$ after different digestion times

\begin{tabular}{llll}
\hline & \multicolumn{3}{c}{$\left.\mathrm{G}_{\mathrm{FM}}\left(\mathrm{L}_{N} \mathrm{CH}_{4} / \mathrm{kg} \text { VS } \mathrm{S}_{\text {added,FM }}\right)^{*}\right)$} \\
\cline { 2 - 4 } & 28 days & 42 days & 74 days \\
\hline experiment 1 & & & \\
FM_percol & 106.3 & 149.5 & 207.0 \\
SI_10 & 135.2 & 167.3 & 200.0 \\
SI_20 & 145.9 & 174.7 & 208.0 \\
SI_30 & 142.0 & 165.6 & 206.3 \\
SI_40 & 145.9 & 169.7 & 207.7 \\
FM_flood & 144.4 & 169.3 & 204.0
\end{tabular}

experiment 2

Percol1; Percol2

$176.6 ; 170.9$

FloodLI1; FloodLI2

171.1; 171.9

FloodPW1; FloodPW2

$153.7 ; 158.8$

ChoppLI1; ChoppLI2

$192.2 ; 192.7$

Aeration

140.2

${ }^{*}$ yield from component fresh material, determined according to section 2.4., methane remaining inside digesters was taken into account 
Table 4

Final VS and nitrogen contents, VS removal from solid phase (SP) and from whole system (solid + liquid phase, $\mathrm{SP}+\mathrm{LP})$, methane yield per $\mathrm{kg}$ VS removed in experiment 2

\begin{tabular}{|c|c|c|c|c|c|}
\hline & Percol1;2 & FloodLI1;2 & FloodPW1;2 & ChoppLI1;2 & Aeration \\
\hline final VS in LP (\% wet w) & $1.01 ; 1.11$ & $0.86 ; 0.82$ & $0.42 ; 0.44$ & $1.16 ; 0.98$ & 0.83 \\
\hline final VS in SP (\% wet w) & $11.58 ; 12.19$ & $10.84 ; 11.03$ & $11.07 ; 11.44$ & $8.85 ; 10.47$ & 10.38 \\
\hline $\begin{array}{l}\text { ratio VS in LP to total VS (LP + } \\
\text { SP) (\%) }{ }^{\text {a }}\end{array}$ & $4.05 ; 4.25$ & $14.56 ; 14.35$ & $8.82 ; 8.77$ & $18.97 ; 16.80$ & 15.13 \\
\hline final $\mathrm{NH}_{4}-\mathrm{N}$ in $\mathrm{LP}(\mathrm{mg} / \mathrm{L})$ & $492 ; 512$ & $320 ; 355$ & $164 ; 131$ & $415 ; 353$ & 243 \\
\hline final TKN in LP (mg/L) & $1051 ; 1049$ & $798 ; 801$ & $462 ; 463$ & $1122 ; 902$ & 790 \\
\hline VS removal from SP (\%) ${ }^{b}$ & $40.5 ; 39.8$ & $50.7 ; 47.9$ & $48.1 ; 46.3$ & $54.7 ; 51.3$ & 51.9 \\
\hline VS removal from SP + LP (\%) ${ }^{c)}$ & $38.8 ; 37.9$ & $45.6 ; 43.0$ & $43.1 ; 41.1$ & $47.5 ; 45.2$ & 46.0 \\
\hline $\begin{array}{l}\text { methane yield per kg VS removed } \\
\left(L_{N} C_{4} H_{4} / k g \vee S_{\text {removed,SP+LP })}\right.\end{array}$ & $412.3 ; 411.1$ & $372.4 ; 396.2$ & $369.8 ; 401.8$ & $396.7 ; 416.0$ & $(301.6)$ \\
\hline $\begin{array}{l}\text { mean biogas methane content }(\% \\
\left.\text { v/v } \mathrm{CH}_{4}\right)\end{array}$ & $51.2 ; 51.1$ & $53.5 ; 53.5$ & $52.4 ; 52.8$ & $53.0 ; 52.6$ & 52.36 \\
\hline $\begin{array}{l}\text { a) }=\left(\mathrm{kg} \vee S_{\mathrm{LP}}\right) /\left(\mathrm{kg} \vee S_{\mathrm{LP}}+\mathrm{kg} \vee S_{\mathrm{SP}}\right)^{\star} \\
\text { phase; } \\
\text { b) }=\left(\mathrm{kg} \vee S_{\text {removed,SP }}\right) /\left(\mathrm{kg} \vee S_{\text {added,SP }}\right)^{\star} \\
\left(\mathrm{kg} \vee S_{\text {added,SP }}\right)=\left(\mathrm{kg} \vee S_{\text {added,FM }}+\mathrm{kg}\right. \\
\text { c) }=\left(\mathrm{kg} \vee S_{\text {removed,SP+LP }}\right) /\left(\mathrm{kg} \vee S_{\text {added,S }}\right. \\
\left.\mathrm{kg} \vee S_{\text {liquid residue }}\right) \text { and }\left(\mathrm{kg} \vee S_{\text {added,SP }}\right.\end{array}$ & $\begin{array}{l}\% \text {; indicates w } \\
0 \% \text {; with (kg Vs } \\
\text { added,SI); FM: fre } \\
\text { P)*100\%; with } \\
=(\mathrm{kg} \mathrm{VS} \text { added,FI }\end{array}$ & $\begin{array}{l}\text { ch proportion o } \\
\text { moved,SP })=(\mathrm{kg} \text { VS } \\
\text { material, SI: } \mathrm{s} \\
\mathrm{VS}_{\text {removed,SP+LP }} \\
\mathrm{kg} \mathrm{VS} \text { added,SI }\end{array}$ & $\begin{array}{l}\text { the final total V } \\
\text { added,SP - kg VS } \\
\text { lid inoculum; } \\
=\left(\mathrm{kg} \vee S_{\text {added,SP }}\right. \\
\left.\mathrm{kg} \vee \mathrm{S}_{\text {added,SI }}\right) ; \mathrm{L}\end{array}$ & $\begin{array}{l}\text { was found in th } \\
\text { d residue) and } \\
\text { - } \mathrm{kg} \mathrm{VS}_{\text {solid resi }} \\
\text { liquid inoculum }\end{array}$ & \\
\hline \multicolumn{6}{|c|}{$\begin{array}{l}\text { Note: all data refer to experimental time of } 46 \text { days; the values for "final VS in SP", "ratio VS in LP to total VS" and } \\
\text { "VS removal from SP" are influenced by phase-separation between solid and liquid phase when emptying the } \\
\text { reactors (not standardized in this study), therefore deviation between replicates might be high (due to different } \\
\text { amounts of liquid retained in the solid phase); in general, phase-separation was carried out by repeatedly } \\
\text { pumping out all liquid from the liquid-phase reservoir before removing the solid residue, but in two flooded } \\
\text { reactors exterior filtering (PVC-cloth, mesh size } 1.9 \times 1.4 \mathrm{~mm} \text { ) was performed because liquid collected very slowly } \\
\text { in the liquid-phase reservoir }\end{array}$} \\
\hline
\end{tabular}




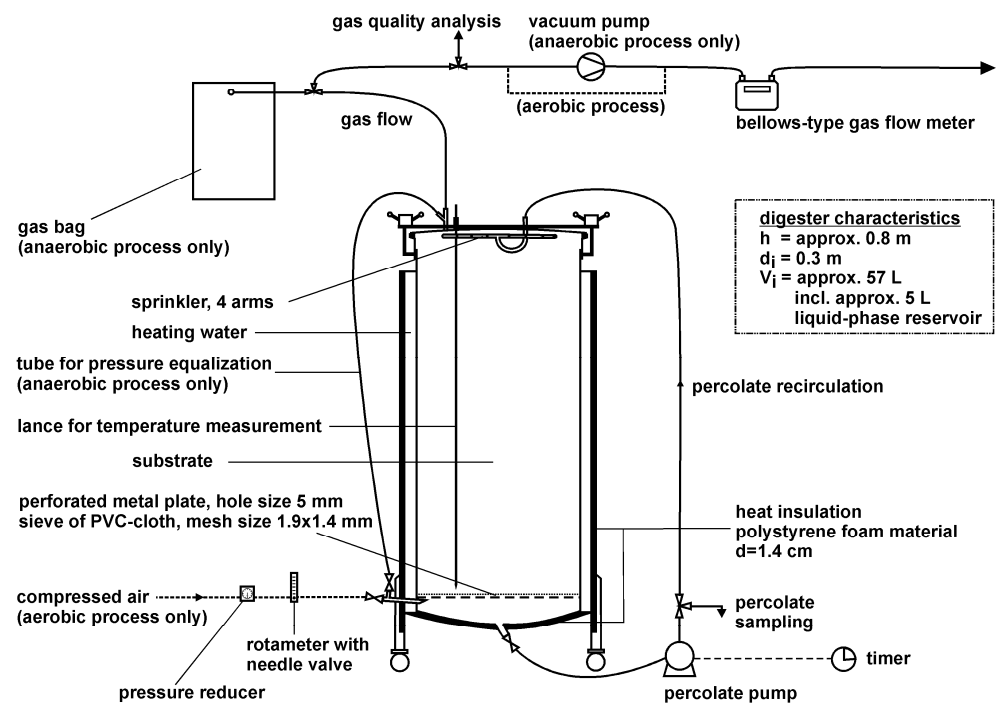

Fig. 1. Schematic diagram of laboratory-scale solid-phase digester
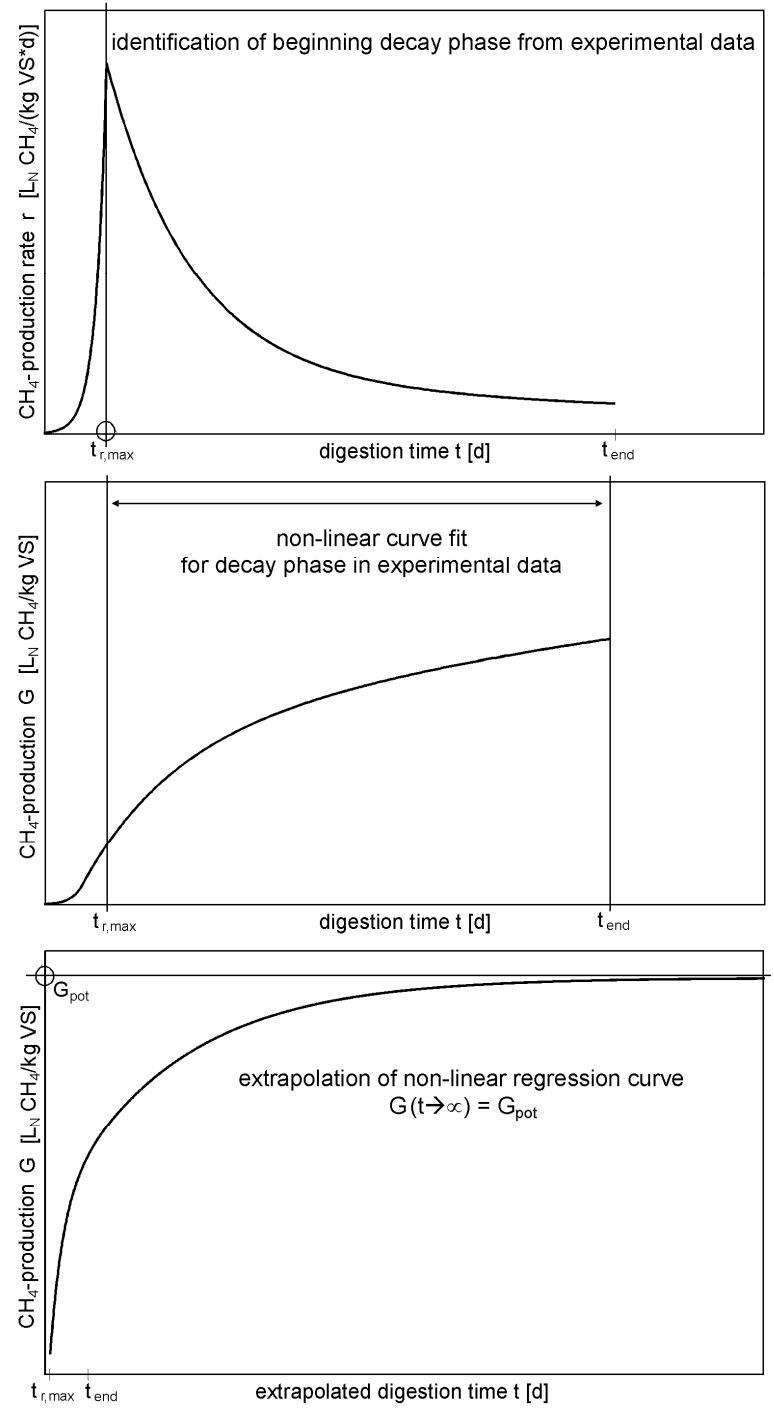

Fig. 2. Methodology for determination of total methane potential $\left(G_{p o t}\right)$ by extrapolation from experimental data 


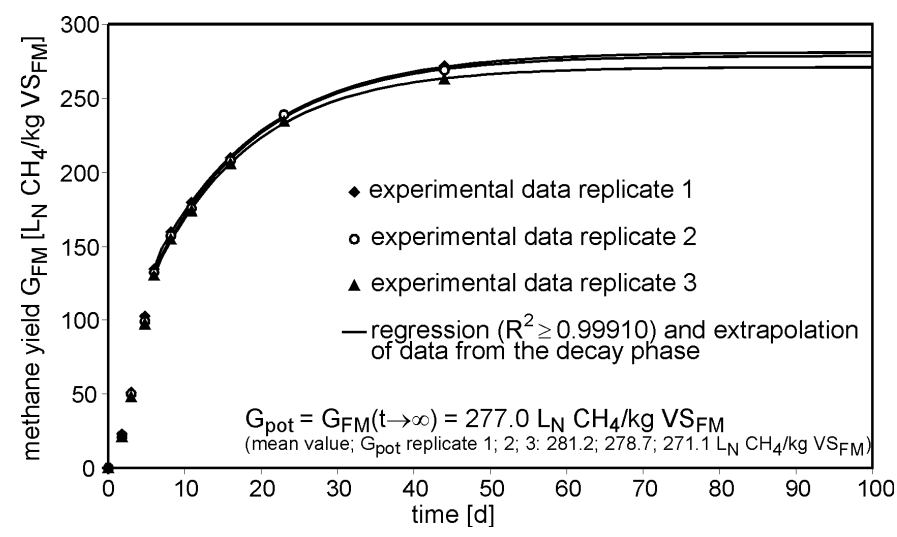

Fig. 3. Determination of total methane potential $\mathrm{G}_{\text {pot }}$ of horse dung by extrapolation from experimental data obtained with ground material in optimized batch-testing (Hohenheim biogas yield test HBT; contribution of inoculum is corrected)

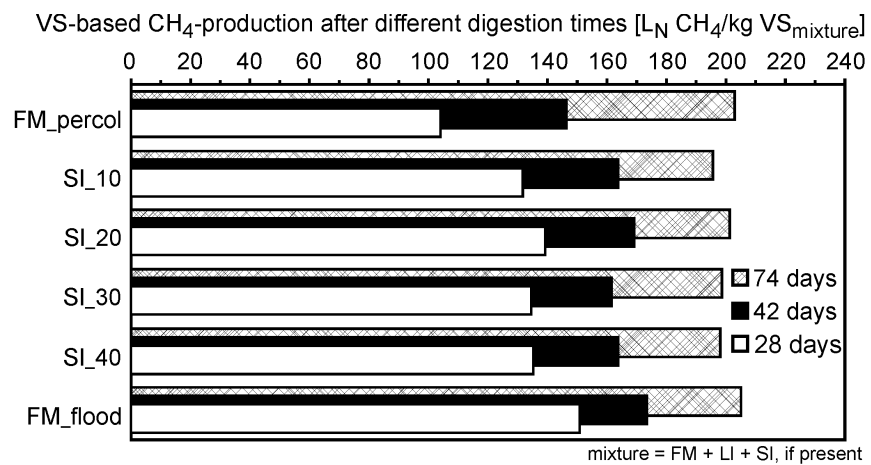

volume-based $\mathrm{CH}_{4}$-production after different digestion times $\left[\mathrm{L}_{\mathrm{N}} \mathrm{CH}_{4} / \mathrm{L}_{\text {solid substrate }}\right]$

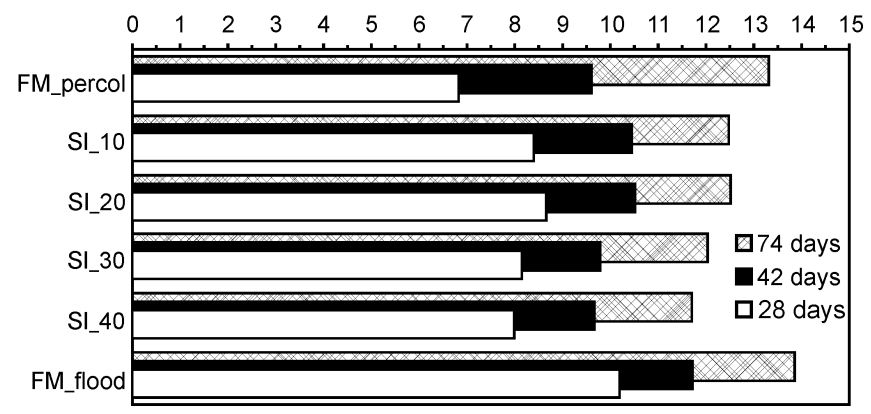

Fig. 4. Methane production in experiment 1 

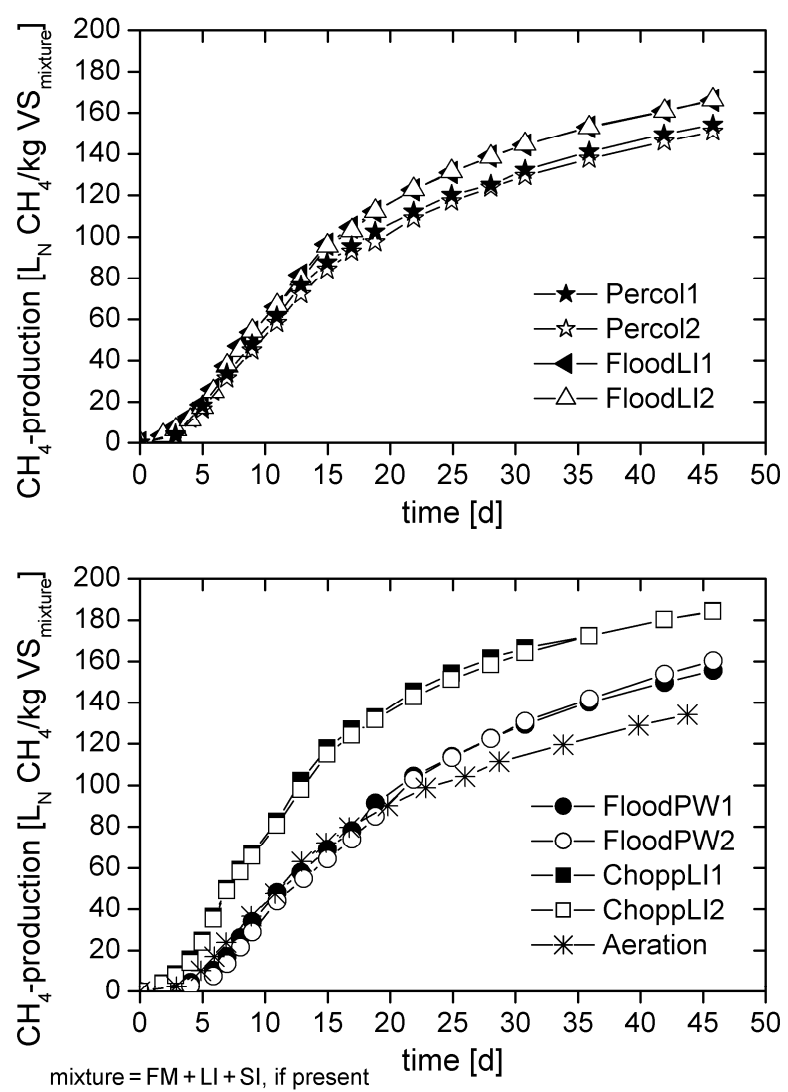

Fig. 5. Methane production in experiment 2

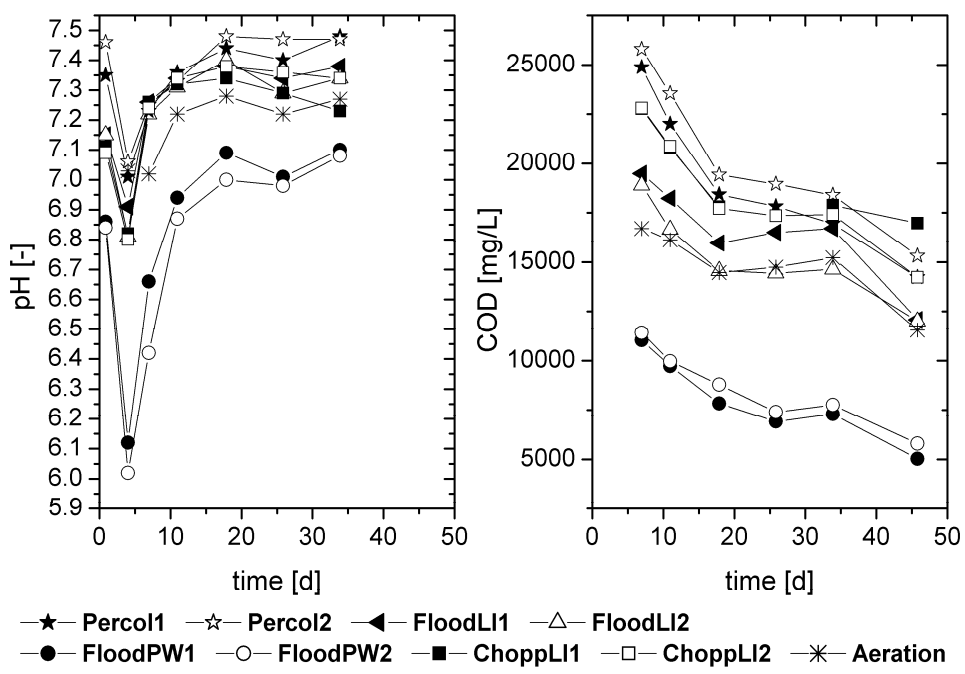

Fig. 6. $\mathrm{pH}$ and $\mathrm{COD}$ in leachate of experiment 2 

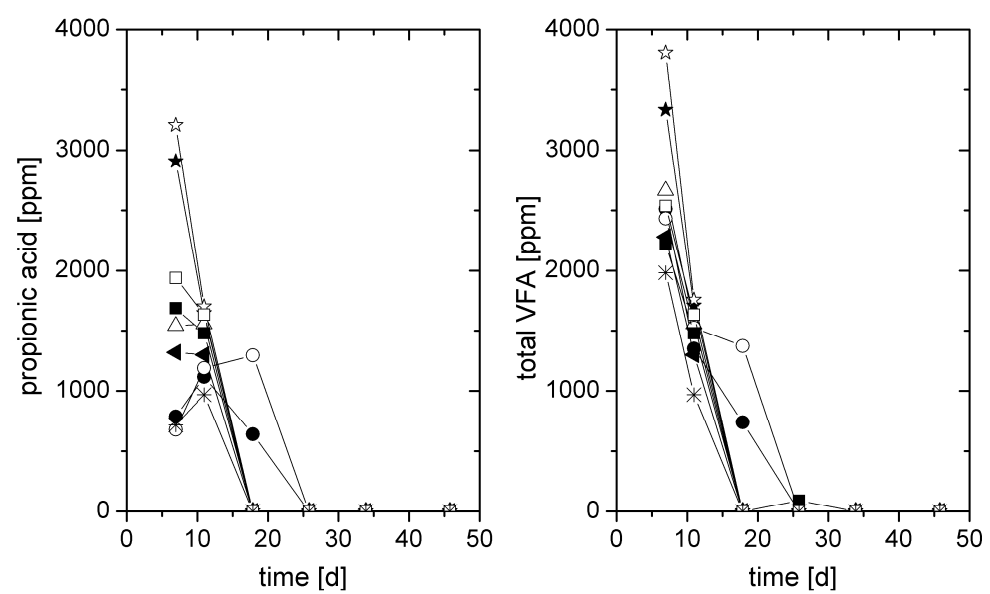

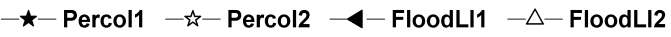

--FloodPW1 -O-FloodPW2 - -ChoppLI1 - - ChoppLI2 - *-Aeration

Fig. 7. Total VFA and propionic acid concentration in leachate of experiment 2
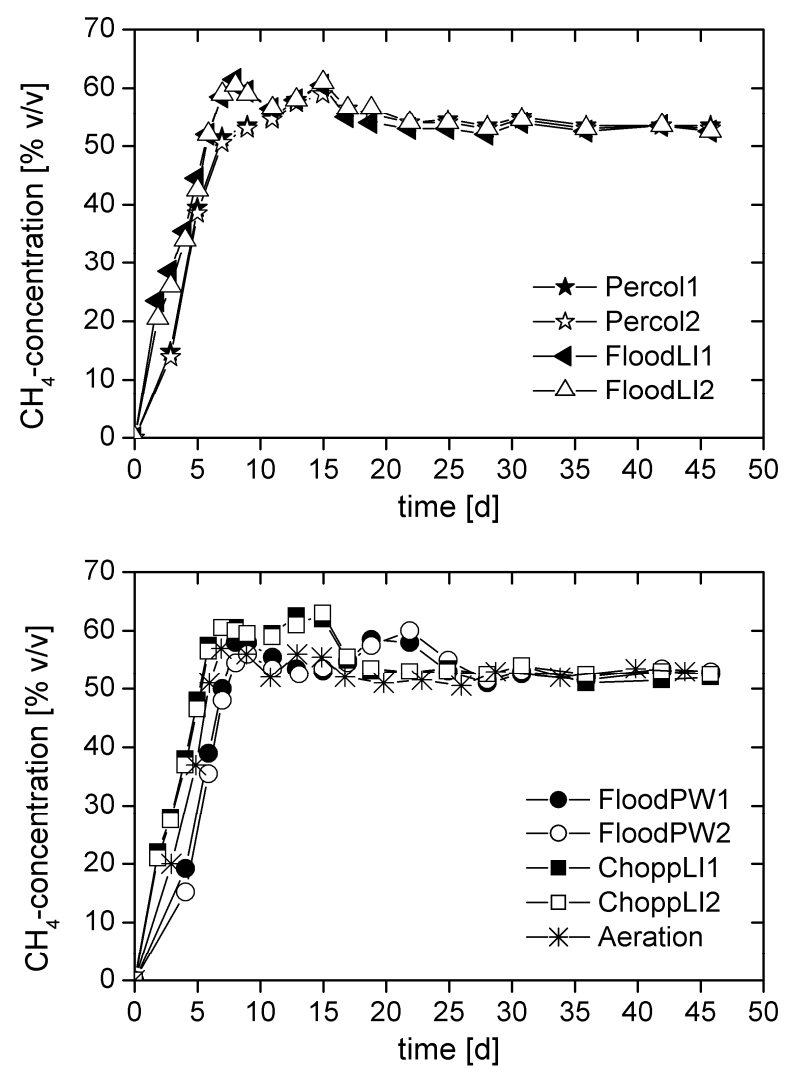

Fig. 8. Biogas methane content in experiment 2 


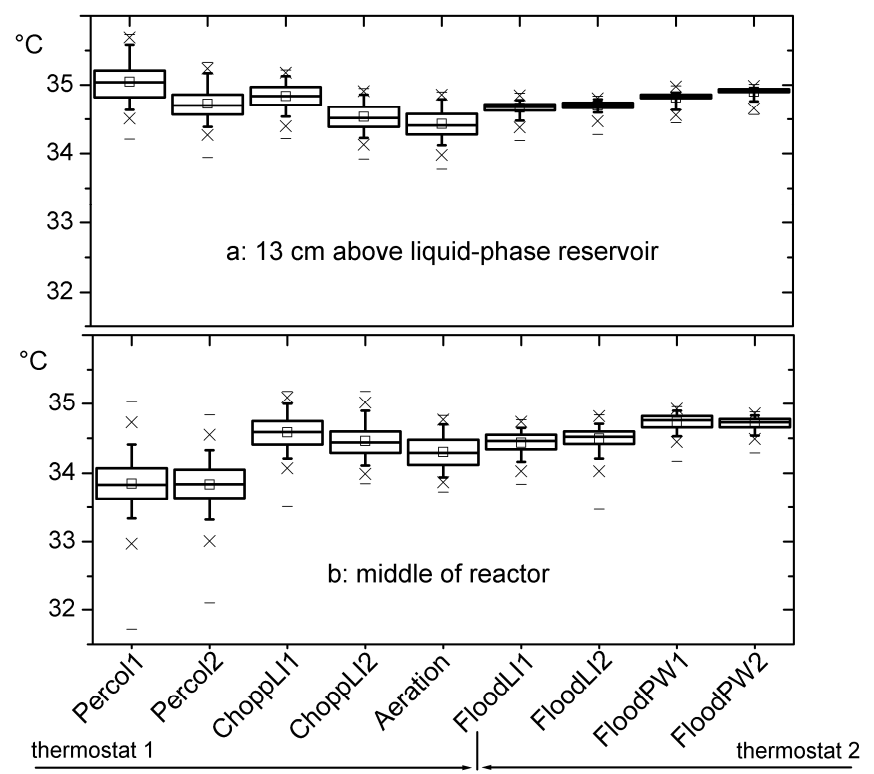

box-whisker-plot: box contains 25 th to 75 th percentile, median (horizontal line) and mean (quadrat) whiskers go to 5th and 95th percentile, $X$ : 1st and 99th percentile, -: minimum and maximum

n=1877 for Percol/ChoppLI/FloodLI/FloodPW1/2; n=1679 for Aeration

all values during the first 24 hours of digestion are ignored

Fig. 9. Substrate temperatures during experiment 2 